\title{
Validity and Reliability of Agility Test with Dribbling and Passing in Soccer Games
}

\author{
Galang Qowiyyuridho ${ }^{1, *}$, Tomoliyus $^{2}$, Fauzi $^{2}$ \\ ${ }^{1}$ Postgraduate Program, Faculty of Sport Science, Universitas Negeri Yogyakarta, Indonesia \\ ${ }^{2}$ Faculty of Sport Science, Universitas Negeri Yogyakarta, Indonesia
}

Received December 22, 2020; Revised February 24, 2021; Accepted March 12, 2021

\begin{abstract}
Cite This Paper in the following Citation Styles
(a): [1] Galang Qowiyyuridho, Tomoliyus, Fauzi, "Validity and Reliability of Agility Test with Dribbling and Passing in Soccer Games, "International Journal of Human Movement and Sports Sciences, Vol. 9, No. 2, pp. 301 - 307, 2021. DOI: 10.13189/saj.2021.090218.
\end{abstract}

(b): Galang Qowiyyuridho, Tomoliyus, Fauzi (2021). Validity and Reliability of Agility Test with Dribbling and Passing in Soccer Games. International Journal of Human Movement and Sports Sciences, 9(2), 301 - 307. DOI: 10.13189/saj.2021.090218.

Copyright $\bigcirc 2021$ by authors, all rights reserved. Authors agree that this article remains permanently open access under the terms of the Creative Commons Attribution License 4.0 International License

\begin{abstract}
This study aims to find the validity and reliability of the agility test with the dribbling and passing of soccer players. Data collection uses the Delphi technique with 5 experts and also test-retest. Twenty football players aged 13-14 years who had been training for one year in junior school soccer classes were used in this study to seek empirical validity and the reliability of the test. Analysis of content validity data uses the Aiken V formula, empiric validity uses Pearson Product Moment and Reliability uses Cronbach's Alpha. The results showed that the agility test with dribble and passing showed a high value of validity and reliability. The Aiken value on the Agility indicator according to the soccer gets a value of 0.87 , the indicator of the level of difficulty following the soccer gets a value of 0.93 , the component herding following the soccer gets a value of 0.87 , the component of the bait component according to the soccer gets a value of 0.87 , the distance indicator for dribbling is following the value of 0.87 , the distance indicator between cones is in the value of 0.93 , the distance indicator for baiting is in the amount of 0.87 , the Instrument indicator safe to do is getting the value of 1.00 , the indicator for short and clear language is in the value of 0.93 . The results of the Pearson Product Moment data analysis results obtained 0.991. The Cronbach's Alpha score is 0.995 . It can be concluded that the agility test with dribble and passing can be used to measure the agility of soccer players.
\end{abstract}

Keywords Validity, Reliability, Agility Test, Soccer

\section{Introduction}

The Factors in soccer sports both technical skills, tactics, mental, and physical abilities such as strength, power, speed, agility will affect performance and success of soccer player [1], [2]. The most important aspect of identifying talent in soccer is the assessment of performance and the ability to execute patterns of movement skillfully, effectively and efficiently [3]. To put pressure on your opponent while defending or to avoid your opponent when attacking, agility is an important quality to have [4]. Motor perception skills that work together in a rapidly changing environment are certainly needed in soccer [5], [6].

Besides the agility test, many physical fitness tests can be done to test the physical capacity of soccer players. Laboratory tests and special soccer field tests can be done to measure fitness for soccer. The validity of laboratory tests for measuring soccer's special capacity is still questionable, although this test is considered to be reliable and useful for measuring general fitness levels [7]. Submaximal running, straight sprints, and agility are some of the traditional fitness tests in soccer [7].

As we know, in soccer game player must move quickly with the situation off the game, especially when the player is in control of the ball. Movement or action with the ball is also included in some special tests in soccer which increases the validity of such tests [2]. Preliminary data about the validity and reliability of the test were obtained from research involving soccer players who used a simple 
protocol that included a test of shooting [8]. However, the static position is carried out as a prefix before firing at the goal, and the actual assessment of the 'technique' and 'skill' can be debated [3]. The ability to pass and dribble or sprint by maintaining ball control is an important technique and is often used in soccer [9]. The ability to dribble in this case dribbling quickly becomes a general measure of skill and is also an important part of determining the outcome of a match [10].

The Loughborough Soccer Passing Test (LSPT) and the Loughborough Soccer Shooting Test (LSST) were developed by [11] because the available skills and technical tests are limited. However, Agility does not specifically target the objectives in this skills-based test. Recently a new test for field-based sports - a test of direction and acceleration (CODAT) was developed by [12] which monitors player performance. However, shooting and dribbling skills are not included in this test. [13] considered these limitations, then developed a test of dexterity and special skills of combined soccer, including running, change of direction, acceleration, deceleration, sprint and backward, and shooting at goal. Dexterity tests and shooting balls for male soccer players are valid. However, the validity and reliability in this test cannot be sure used by female amateur soccer players. Male players form the basis for testing and fitness performance in several test reports, and few women are involved [14] [16]. Then research [17] redevelops the validity and reliability of agility and skill tests for amateur female soccer players. However, in both studies the component skills tests used only passing skills and also there is still minimal research conducted related to the agility test instrument that resembles a soccer game situation. Therefore, the purpose of this study is to find the validity and reliability of the agility test with specific soccer skills which also includes passing skills and dribbling components.

\section{Method}

\subsection{Materials and Procedures}

Twenty football players aged 13-14 years who had been training for one year in junior school soccer classes were used in this study to seek empirical validity and instrument reliability. Data collection was agreed by the trainer from the school. The players are in good health while doing the test. Before conducting the test, players get an explanation of this research.

Evaluation of the validity of the agility component in soccer uses content validity and empirical validity. Content validity is done in 2 steps, the first step has 2 stages, the first stage is collecting relevant sources or data and conducting preliminary studies and conducting surveys or interviews with the coach. The second stage after collecting data is to evaluate all the data that has been obtained

The second step is to carry out the Delphi method by submitting an assessment to 5 experts by assessing the instrument content including important or unimportant categories. The third step is conducting data processing and testing of the results of expert validation, there are two data obtained, the first data are quantitative data from expert judgment by evaluating 4 categories, the Aiken V formula is used to analyze the data. Suggestions obtained from experts to input assessment instruments are the second data in the form of qualitative data.

The content validity of this instrument was estimated using the Delphi panel technique. The Delphi panel technique is used to make agreements from experts using several stages (3-5). Expert panelists' opinions are used in this technique and anonymity among expert panelists is maintained [18], [23]. The Delphi method is a method used to reach experts' opinions on a particular subject in a gradual and repetitive process [24]. Delphi technique in determining content validity is more popular because according to some researchers, FGD techniques often feel forced to attend and the discussion process is usually dominated by one or several experts [22]. Questions about panelists or selected experts also remain a research bias throughout sources or literature [19],[20]. However, panelists will be of quality if the input given by panelists is fair on the topic and not impartial [21].

Assessment of Empirical Validity and Reliability Using 2 steps, the first is to do a test-retest. The instrument was tested on 20 amateur soccer players 2 times. The number of samples that can be used to perform a reliability test has been proposed as many as 40 people [40]. However, in its application it will be difficult to achieve this amount in a homogeneous sample. Therefore, research to determine reliability in a smaller sample size can be carried out [41],[42]. The rest between the two tests is noted to keep the conditions on the second test the same as the first test. Test-retest is used by doing the test more than twice with the same situation to the same participant. After completing each test, a statistical comparison can be obtained [25]. Then empiric validity was calculated using the Pearson Product Moment test and reliability using data analysis with Cronbach's alpha technique.

\subsection{Data Analysis}

The data analysis technique used to determine validity is to use a formula according to [26], [27] where each item in each component is calculated for its validity index by calculating:

$$
\mathrm{V}=\sum \mathrm{s} /[\mathrm{n}(\mathrm{C}-1)]
$$

$$
\begin{aligned}
& \mathrm{S}=\mathrm{r}-\mathrm{lo} \\
& \text { Lo }=\text { lowest score } \\
& \mathrm{C}=\text { highest score }
\end{aligned}
$$


$\mathrm{R}=$ number given by the assessor

The empiric validity uses the Pearson Product Moment test. Whereas to determine the reliability value is to use Cronbach alfa analysis. This technique determines the consistency of an instrument and is often used. The results of Cronbach alpha are between the numbers 0 and 1 . If the score obtained is 0.7 or higher then reliability can be accepted [28].

\section{Results}

\subsection{Content Validity}

The results of the analysis using the Aiken formula are shown in table 1.

Based on table 1 the Aiken value on the Agility indicator according to the soccer branch gets a value of 0.87 , the indicator of the level of difficulty following the soccer branch gets a value of 0.93 , the component herding following the soccer branch gets a value of 0.87 , the component of the bait component according to the soccer branch gets a value of 0.87 , the distance indicator for dribbling is following the value of 0.87 , the distance indicator between cones is in the value of 0.93 , the distance indicator for baiting is in the amount of 0.87 , the Instrument indicator is safe to do is getting the value of 1.00 , the indicator for short and clear language is in the value of 0.93 . The value of these items when compared to the standard table values compiled by Aiken [27], using 4 rating categories and 5 rater, then the minimum standard Aiken $\mathrm{V}$ for this study is 0.80 , it can be said that the results of the agility test item values are valid in content. Aiken $\mathrm{V}$ value of 0.41 to 0.60 is said to have a moderate agreement. if the value of Aiken $\mathrm{V}$ is 0.81 to 1.00 then it is said to have a high agreement [29]. Based on these two opinions it can be said that the agility test with dribbling and passing has high validity. In other words all experts have a high agreement. Also there are improvements to the agility test construction as shown in Figure 1.

Table 1. Results of Aiken $\mathrm{V}$ analysis

\begin{tabular}{|c|c|c|c|c|c|c|c|c|c|c|c|c|c|c|c|c|c|c|}
\hline \multirow{2}{*}{ Asessor } & \multicolumn{2}{|c|}{ Item 1} & \multicolumn{2}{|c|}{ Item 2} & \multicolumn{2}{|c|}{ Item 3} & \multicolumn{2}{|c|}{ Item 4} & \multicolumn{2}{|c|}{ Item 5} & \multicolumn{2}{|c|}{ Item 6} & \multicolumn{2}{|c|}{ Item 7} & \multicolumn{2}{|c|}{ Item 8} & \multicolumn{2}{|c|}{ Item 9} \\
\hline & Scores & $\mathrm{s}$ & Scores & $\mathrm{s}$ & Scores & $\mathrm{s}$ & Scores & $\mathrm{s}$ & Scores & $\mathrm{s}$ & Scores & $\mathrm{s}$ & Scores & $\mathrm{s}$ & Scores & $\mathrm{s}$ & Scores & $\mathrm{s}$ \\
\hline A & 4 & 3 & 3 & 2 & 4 & 3 & 4 & 3 & 3 & 2 & 3 & 2 & 3 & 2 & 4 & 3 & 4 & 3 \\
\hline B & 3 & 2 & 4 & 3 & 4 & 3 & 3 & 2 & 4 & 3 & 4 & 3 & 4 & 3 & 4 & 3 & 4 & 3 \\
\hline $\mathrm{C}$ & 4 & 3 & 4 & 3 & 3 & 2 & 4 & 3 & 4 & 3 & 4 & 3 & 3 & 2 & 4 & 3 & 4 & 3 \\
\hline D & 4 & 3 & 4 & 3 & 3 & 2 & 4 & 3 & 3 & 2 & 4 & 3 & 4 & 3 & 4 & 3 & 4 & 3 \\
\hline $\mathrm{E}$ & 3 & 2 & 4 & 3 & 4 & 3 & 3 & 2 & 4 & 3 & 4 & 3 & 4 & 3 & 4 & 3 & 3 & 2 \\
\hline $\mathrm{s}$ & \multicolumn{2}{|l|}{13} & \multicolumn{2}{|l|}{14} & \multicolumn{2}{|l|}{13} & \multicolumn{2}{|l|}{13} & \multicolumn{2}{|l|}{13} & \multicolumn{2}{|l|}{14} & \multicolumn{2}{|l|}{13} & \multicolumn{2}{|c|}{15} & \multicolumn{2}{|c|}{14} \\
\hline V & \multicolumn{2}{|c|}{0.87} & \multicolumn{2}{|c|}{0.93} & \multicolumn{2}{|c|}{0.87} & \multicolumn{2}{|l|}{0.87} & \multicolumn{2}{|c|}{0.87} & \multicolumn{2}{|c|}{0.93} & \multicolumn{2}{|c|}{0.87} & \multicolumn{2}{|c|}{1.00} & \multicolumn{2}{|c|}{0.93} \\
\hline
\end{tabular}

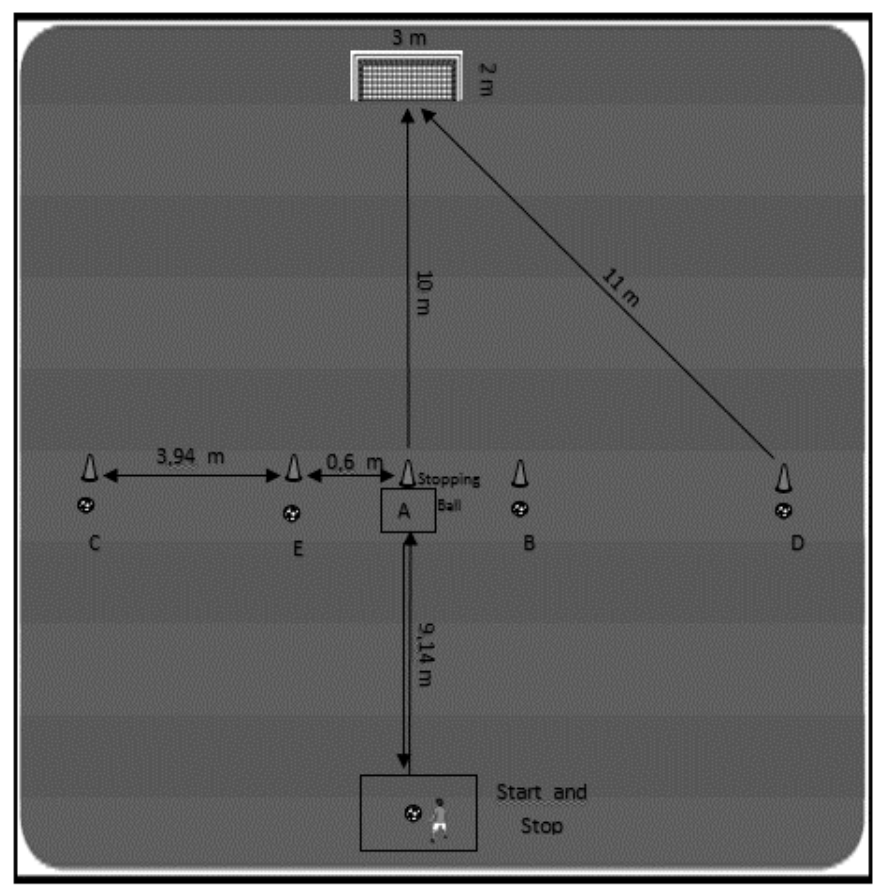

Figure 1. Agility Test Instrument with Dribble and Passing for Soccer Players 


\subsection{Empiric Validity}

The results of empirical validity analysis can be seen in the Table 2.

Table 2. Results of Pearson Product Moment Analysis

\begin{tabular}{|c|c|c|c|}
\hline \multicolumn{4}{|c|}{ Correlations } \\
\hline \multirow{4}{*}{ Test 1} & Test 1 & Test 2 \\
\cline { 2 - 4 } & Pearson Correlation & 1 & $.991^{* *}$ \\
\cline { 2 - 4 } & Sig. (2-tailed) & & .000 \\
\cline { 2 - 4 } & $\mathrm{N}$ & 20 & 20 \\
\hline \multirow{3}{*}{ Test 2} & Pearson Correlation & $.991^{* *}$ & 1 \\
\cline { 2 - 4 } & Sig. (2-tailed) & .000 & \\
\cline { 2 - 4 } & $\mathrm{N}$ & 20 & 20 \\
\hline
\end{tabular}

** Correlation is significant at the 0.01 level (2-tailed).

Table 2 shows the results of the Pearson Product Moment data analysis results obtained 0.991 . by comparing with $\mathrm{r}$ tables for $\mathrm{N}$ totaling 20 and the significance value of $5 \%$, then $r$ count is greater than $r$ tables. The significance value is also $<0.05$, so it can be stated that this agility test instrument is valid.

\subsection{Reliability Results}

The results of the reliability of the agility test with dribbling and passing of soccer players like table 3 are as follows.

Table 3. Results of Cronbach alpha analysis

\begin{tabular}{|c|c|c|}
\hline \multicolumn{3}{|c|}{ Reliability Statistics } \\
\hline Cronbach's Alpha & $\begin{array}{c}\text { Cronbach's Alpha Based on } \\
\text { Standardized Items }\end{array}$ & N of Items \\
\hline 0.995 & 0.996 & 2 \\
\hline
\end{tabular}

Based on Table 3, the Cronbach's Alpha score is 0.995, so the agility test instrument with dribble and passing skills for soccer players has high reliability because it has a value of more than 0.7 .

Equipment:

- The field used is grass field

- Soccer shoes

- 5 balls

- Cones

- $2 \times 3 m$ hurdles

- $\quad$ Stopwatch

Procedure for conducting tests.

1. The starting position of the player is in the start box when the player first touches the ball to dribble, then the time starts

2. Players dribble and stop the ball to point A

3. Follow by running as fast as possible to point $\mathrm{B}$, then push the ball to the right so that the ball is beside the cone and passed to the goal with the right foot
4. The player runs back as fast as possible to point $\mathrm{C}$ and pushes the ball to the left so that the ball is beside the cone followed passing with the left foot

5. Then the player makes the same move to point $D$ and pushes the ball and kicks the ball with his right foot, then to point $\mathrm{E}$ and pushes and kicks the ball with his left foot

6. The players returns to point A and dribbles again and stops the ball in the stop box then the time is stopped.

7. The players are allowed to do 2 times the smallest time taken.

\section{Discussion}

The skill component in soccer has been widely explained by research such as basic kicking abilities, however, agility and skills are still few that combine and also serve as an item test tool. [13], [30]. Male players form the basis for testing and fitness performance in several test reports [14]-[16]. Then research [17] redeveloped the validity of agility and skill tests for amateur female soccer players. The understanding of agility in most studies is mentioned to be able to describe a combination of a decrease in speed, change of direction, and acceleration that is fast and effective while still being able to maintain motor control after the response to a given stimulus such as opposing player movements or ball movements [31][32]. In sports games such as soccer, players must be able to do good moves in different directions and maybe also in tight spaces [33]. Agility is an important physical component to be able to improve performance in a variety of sports, so does soccer and should be included in training program [34]. Soccer player's performance can also be said to be good and quality when the player also can stop, start, and change direction quickly [35]. There are so many ways that have been used to reach to find out one's physical abilities, especially in agility. Agility tests can also help to determine player performance indicators because agility is also a component of fitness related skills so it is required in tests for soccer players. [36].

The results obtained from the experts (Table 1) show the Agility Indicator following the soccer branch getting a value of 0.87 , the indicator of the level of difficulty following the soccer branch getting a value of 0.93 , the component herding following the soccer branch earns a value of 0.87 , the component indicator feed following soccer branches get a value of 0.87 , the distance indicator for dribbling already matches a value of 0.87 , a distance indicator between cones has a value of 0.93 , the distance indicator for baiting is appropriate for a value of 0.87 , the Instrument indicator safe to do gets a value of 1.00 , the indicator of short and clear language gets a value of 0.93 . The results of the Aiken value show all indicators whose values are above 0.70 , it can be stated that all indicators 
have high content validity [30], [37]. Empirical validity using Pearson product-moment test found the value of $r$ count $>$ from $r$ table then declared valid. Cronbach's Alpha score of 0.995 , the agility test instrument with dribble and passing skills for soccer players has high reliability because it has a value of more than 0.7 [28]. Therefore, the construction of the test is feasible to use for testing agility with dribbling and passing. This test is the development of the agility test combined with the skill component in soccer so that it can bring up situations that are following the actual state of the game. Not only in terms of distance that shows the actual state of the game, the different types of motion that appear in the game can also reflect that the test can show the actual state in a sports game [5].

In the development of this agility test combined with components of dribbling and passing. Players must be able to make passes using the right foot and left by pushing the ball first. The ball is pushed to create a state in the game that they kick the ball in a state of motion. This certainly requires the ability of athletes to make decisions on the game of soccer-related to their physical and cognitive abilities. In other words, decision making must be done as quickly as possible by the players in this test [6], [38], [39]. Previous research conducted by [13], [17] which compared agility tests using passing with various agility tests such as T-test, Illinois, and Zigzag also showed high validity and reliability results. Dribble skills are also used in the development of this test, because the ability to pass and dribble or sprint by maintaining ball control is an important technique and is often used in soccer [9].

This study has limitations that could be developed by further research. The number of samples in this study amounted to 20 people. The number of samples that can be used to perform a reliability test has been proposed as many as 40 people [40]. However, in its application it will be difficult to achieve this amount in a homogeneous sample. Therefore, research to determine reliability in a smaller sample size can be carried out [41],[42]. Research in a sample size of 20 was also carried out to determine the reliability of test instruments in soccer [43].

\section{Conclusions}

Based on the data obtained and through the discussion, the protocol used in this study provide measures of agility of soccer player with the situation of the game when player handling the ball. The data of validity and reliability of the test can be concluded that the agility test instrument with dribble and passing skills for soccer players has content validity with high scores and this test can be used to test the agility of a soccer game.

\section{REFERENCES}

[1] R. G. Lockie, A. B. Schultz, S. J. Callaghan, M. D. Jeffriess, \& S. P. Berry, "Reliability and Validity of a New Test of Change-of-Direction Speed for Field- Based Sports: The Change-of-Direction and Acceleration Test (CODAT)." Journal of Sports Science and Medicine, Vol.12, No.1, pp.88-96, 2013.

[2] A. Ali, "Measuring Soccer Skill Performance: A Review." Scandinavian Journal of Medicine and Science in Sports, Vol.21, No.2, pp.170-183, 2011. DOI:10.1111/j.1600-0838 $.2010 .01256 . x$.

[3] W. B. Young \& B. Willey, "Analysis of a Reactive Agility Field Test." Journal of Science and Medicine in Sport, Vol.13, No.3, pp.376-378, 2010. DOI:10.1016/j.jsams.200 9.05.006.

[4] W. Bullock, D. Panchuk, J. Broatch, R. Christian, \& N. K. Stepto, "An Integrative Test of Agility, Speed and Skill in Soccer: Effects of Exercise." Journal of Science and Medicine in Sport, Vol.15, No.5, pp.431-436, 2012. DOI:10.1016/j.jsams.2012.03.002.

[5] J. Sheppard \& W. Young, "Agility Literature Review: Classifications, Training and Testing." Journal of Sports Sciences, Vol.24, No.9, pp.919-932, 2006.DOI:10.1080/02 640410500457109 .

[6] A. Aandstad \& E. V. Simon, "Reliability and Validity of the Soccer Specific Inter Field Test.” Journal of Sports Sciences, Vol.31, No.13, pp.1383-1392, 2013.DOI:10.1080/0264041 4.2013.781667.

[7] T. Stølen, K. Chamari, C. Castagna, \& U. Wisløff, "Physiology of Soccer: An Update." Sports Medicine, Vol.35, No.6, pp.501-536, 2005. DOI:10.2165/00007256-2 00535060-00004

[8] Kutlu M, Yapici H, Yilmaz A. "Reliability and Validity of a New Test of Agility and Skill for Female Amateur Soccer Players". Journal of Human Kinetic, Vol.12, No.56, pp.219-227, 2017. doi: 10.1515/hukin-2017-0039. PMID: 28469760 ; PMCID: PMC5384069.

[9] T. Reilly, A. M. Williams, A. Nevill, \& A. Franks, "A Multidisciplinary Approach to Talent Identification in Soccer." Journal of Sports Sciences, Vol.18, No.9, pp.695702, 2000. DOI:10.1080/02640410050120078.

[10] B. C. H. Huijgen, M. T. Elferink-Gemser, W. J. Post, \& C. Visscher, "Soccer Skill Development in Professionals." International Journal of Sports Medicine, Vol.30, No.8, pp.585-591, 2009. DOI:10.1055/s-0029-1202354.

[11] A. Ali, C. Williams, M. Hulse, A. Strudwick, J. Reddin, L. Howarth, J. Eldred, M. Hirst, \& S. McGregor, "Reliability and Validity of Two Tests of Soccer Skill." Journal of Sports Sciences, Vol.25, No.13, pp.1461-1470, 2007. DOI: $10.1080 / 02640410601150470$.

[12] R. G. Lockie, A. J. Murphy, T. J. Knight, \& X. A. K. J. De Jonge, "Factors That Differentiate Acceleration Ability in Field Sport Athletes." Journal of Strength and Conditioning Research, Vol. 25, No. 10, pp. 2704-2714, 2011. DOI:10.1519/JSC.0b013e31820d9f17. 
[13] M. Kutlu, H. Yapici, O. Yoncalik, \& S. Çelik, "Comparison of a New Test for Agility and Skill in Soccer with Other Agility Tests." Journal of Human Kinetics, Vol.33, No.1, pp.143-150, 2012. DOI:10.2478/v10078-012-0053-1.

[14] A. Ali, A. Foskett, \& N. Gant, "Validation of a Soccer Skill Test for Use with Females." International Journal of Sports Medicine, Vol.29, No.11, pp.917-921, 2008. DOI:10.1055/s-2008-1038622.

[15] J. D. Vescovi \& T. G. Favero, "Motion Characteristics of Women's College Soccer Matches: Female Athletes in Motion (Faim) Study." International Journal of Sports Physiology and Performance, Vol.9, No.3, pp.405-414, 2014. DOI:10.1123/IJSPP.2013-0526.

[16] T. W. Kaminski, E. S. Cousino, \& J. J. Glutting, "Examining the Relationship between Purposeful Heading in Soccer and Computerized Neuropsychological Test Performance." Research Quarterly for Exercise and Sport, Vol.79, No.2, pp.235-44, 2008. DOI:10.1080/02701367.2008.10599486.

[17] M. Kutlu, H. Yapici, \& A. Yilmaz, "Reliability and Validity of a New Test of Agility and Skill for Female Amateur Soccer Players." Journal of Human Kinetics, Vol.56, No.1, pp.219-227, 2017. DOI:10.1515/hukin-2017-0039.

[18] S. Keeney, F. Hasson, \& H. McKenna, "Consulting the Oracle: Ten Lessons from Using the Delphi Technique in Nursing Research.” Journal of Advanced Nursing, Vol.53, No.2, pp.205-212, 2006. DOI:10.1111/j.1365-2648.2006.0 3716.x.

[19] S. Keeney, F. Hasson, \& H. P. McKenna, "A Critical Review of the Delphi Technique as a Research Methodology for Nursing." International Journal of Nursing Studies, Vol.38, No.2, pp.195-200, 2001. DOI:10.1016/S0020-7489(00)000 44-4.

[20] J. Landeta, "Current Validity of the Delphi Method in Social Sciences." Technological Forecasting and Social Change, Vol.73, No.5, pp.467-482, 2006. DOI:10.1016/j.techfore.2 005.09.002.

[21] C. M. Goodman, "The Delphi Technique: A Critique." Journal of Advanced Nursing, Vol.12, No.6, pp.729-734, 1987. DOI:10.1111/j.1365-2648.1987.tb01376.x.

[22] N. Jairath \& J. Weinstein, "The Delphi Methodology (Part One): A Useful Administrative Approach." Canadian journal of nursing administration, Vol.7, No.3, pp.29-42, 1994.

[23] N. Bennett, W. R. Borg, \& M. D. Gall, "Educational Research: An Introduction.” British Journal of Educational Studies, Vol.32, No.3, pp.274, 1984. DOI:10.2307/3121583.

[24] F. Hasson, S. Keeney, \& H. McKenna, "Research Guidelines for the Delphi Survey Technique." Journal of Advanced Nursing, Vol.32, No.4, pp.1008-1015, 2000. DOI:10.1046/j.1365-2648.2000.t01-1-01567.x.

[25] R. Heale \& A. Twycross, "Validity and Reliability in Quantitative Studies." Evidence-Based Nursing, Vol.18, No.3, pp.66-67, 2015. DOI:10.1136/eb-2015-102129.

[26] L. R. Aiken, "Content Validity and Reliability of Single Items or Questionnaires." Educational and Psychological Measurement, Vol.40, No.4, pp.955-959, 1980. DOI:10.1177/001316448004000419.
[27] L. R. Aiken, "Three Coefficients for Analyzing the Reliability and Validity of Ratings." Educational and Psychological Measurement, Vol.45, No.1, pp.131-142, 1985. DOI:10.1177/0013164485451012.

[28] G. Lobiondo-Wood \& J. Haber, Nursing research in Canada. Methods, critical appraisal, and utilization., 3rd ed (Toronto: Elsevier, 2013).

[29] H. Hendryadi, "Validitas Isi: Tahap Awal Pengembangan Kuesioner." Jurnal Riset Manajemen dan Bisnis (JRMB) Fakultas Ekonomi UNIAT, Vol.2, No.2, pp.169-178, 2017. DOI:10.36226/jrmb.v2i2.47.

[30] T. Little \& A. G. Williams, "Specificity of Acceleration, Maximum Speed, and Agility in Professional Soccer Players." Journal of Strength and Conditioning Research, Vol.19, No.1, pp.76-78, 2005. DOI:10.1519/14253.1.

[31] T. Reilly, J. Bangsbo, \& A. Franks, "Anthropometric and Physiological Predispositions for Elite Soccer." Journal of Sports Sciences, Vol.18, No.9, pp.669-83, 2000. DOI:10.1080/02640410050120050.

[32] J. M. Sheppard, W. B. Young, T. L. A. Doyle, T. A. Sheppard, \& R. U. Newton, "An Evaluation of a New Test of Reactive Agility and Its Relationship to Sprint Speed and Change of Direction Speed." Journal of Science and Medicine in Sport, Vol.9, No.4, pp.342-349, 2006. DOI:10.1016/j.jsams.2006.05.019.

[33] J. Bloomfield, R. Polman, \& P. O’Donoghue, "Physical Demands of Different Positions in FA Premier League Soccer." Journal of Sports Science and Medicine, Vol.6, No.1, pp.63-70, 2007.

[34] Young, W. B., and Willey, B. "Analysis of a Reactive Agility Field Test." Journal of Science and Medicine. Vol.13, No.3 pp.376-378, 2009. doi: 10.1016/j.jsams.2009.05.006

[35] Bloomfield J, Polman R, O’Donoghue P. "Deceleration Movements Performed during FA Premier League Soccer Matches.” Journal of Sports Science Medicine. Vol.6, No.10, pp.63-70, 2007.

[36] Svensson M, Drust B. "Testing Soccer Players". Journal of Sports Science, Vol.23, No.6, pp.601-18, 2005. doi: $10.1080 / 02640410400021294$.

[37] P. Ghauri \& K. Gronhaug, Research Method in Business Studies, 4th ed (London: Pearson, 2010).

[38] G. Tenenbaum, N. Levy-Kolker, S. Sade, D. G. Liebermann, \& R. Lidor, "Anticipation and Confidence of Decisions Related to Skilled Performance." International Journal of Sport Psychology, Vol.27, No.3, pp.293-307, 1996.

[39] G. Jordet, E. Hartman, C. Visscher, \& K. A. P. M. Lemmink, "Kicks from the Penalty Mark in Soccer: The Roles of Stress, Skill, and Fatigue for Kick Outcomes." Journal of Sports Sciences, 2007. DOI:10.1080/02640410600624020.

[40] Atkinson, G., \& Nevill, A. M. "Statistical Methods for Assessing Measurement Error (Reliability) in Variables Relevant to Sports Medicine." Sports Medicine, Vol.26, No.4, pp.217-238. 1998. doi: 10.2165/00007256-19982604 $0-00002$.

[41] Mirkov, D., Nedeljkovic, A., Kukolj, M., Ugarkovic, D., \& Jaric, S. "Evaluation of the Reliability of Soccer-Specific Field Tests". Journal of Strength and Conditioning Research, 
Vol.22, No.4,pp.1046-1050, 2008. doi: 10.1519/JSC.0b01 3e31816eb4af.

[42] Ali, A., Foskett, A., \& Gant, N. "Validation of a Soccer Skill Test for Use with Females". International Journal of Sports Medicine, Vol. 29, No.11, pp.917-921, 2008. doi: $10.1055 / \mathrm{s}-2008-1038622$.
[43] Russell M, Benton D, Kingsley M. "Reliability and Construct Validity of Soccer Skills Tests that Measure Passing, Shooting, and Dribbling." Journal Sports Science, Vol.28, No.13, pp.1399-408, 2010. doi: 10.1080/02640414. 2010.511247. PMID: 20967673. doi: 10.1080/02640414.20 10.511247. 